\title{
NOTES
}

\section{ON THE SITE OF ACTION} OF BOTTROMYGIN $A_{2}$

\author{
Tadatoshr Kinoshita and \\ Nobuo Tanaka
}

Institute of Applied Microbiology, University of Tokyo, Bunkyo-ku, Tokyo, Japan

(Received for publication April 15, 1970)

Bottromycin $A_{2}$, a peptide antibiotic, inhibits protein synthesis of bacteria ${ }^{1)}$. It was observed previously that the inhibition of cell-free polypeptide synthesis by the antibiotic was decreased with increasing amounts of ribosomes ${ }^{2)}$. From this it was suggested that bottromycin $A_{2}$ acts on ribosome. The present study is concerned with determining the subunit of the ribosome on which the antibiotic acts.
First, it was studied which subunit is responsible for the effect against the inhibition by bottromycin $\mathrm{A}_{2}$, by examining the inhibition in a protein synthesizing system containing excess of $30 \mathrm{~S}$ or $50 \mathrm{~S}$ ribosomal subunit. As Table 1 shows, the presence of excess of $50 \mathrm{~S}$ over $30 \mathrm{~S}$ subunit decreased the inhibition by bottromycin $\mathrm{A}_{2}$ of poly A-directed synthesis of polylysine. In contrast, no such effect was seen with the reversed combination of subunits. Similar effects were observed with inhibition by erythromycin which was used as a control, since it is known to act on the $50 \mathrm{~S}$ subunit $^{3,4)}$. It follows from these results that bottromycin $\mathrm{A}_{2}$ acts on $50 \mathrm{~S}$ subunit.

The effect of pretreatment of separate subunits with bottromycin $A_{2}$ was also studied. As illustrated in Fig. 1, pretreatment of $50 \mathrm{~S}$ subunit with the antibiotic caused more profound inhibition of poly Adirected synthesis of poly-lysine than pre-

Table 1. Inhibition by bottromycin $A_{2}$ and erythromycin of poly A-directed synthesis of polylysine in the presence of $30 \mathrm{~S}$ or $50 \mathrm{~S}$ ribosomal subunit in excess

\begin{tabular}{|c|c|c|c|c|c|}
\hline & \multicolumn{2}{|c|}{ Ribosomal subunits $\left(A_{260}\right)$} & \multicolumn{2}{|c|}{$\begin{array}{l}{ }^{14} \mathrm{C}-\mathrm{L} y \operatorname{sine} \text { polymerized } \\
(\mathrm{cpm})\end{array}$} & \multirow{2}{*}{$\begin{array}{l}\text { Inhibition } \\
(\%)\end{array}$} \\
\hline & $30 \mathrm{~S}$ & $50 \mathrm{~S}$ & $\begin{array}{l}\text { Without } \\
\text { antibiotic }\end{array}$ & $\begin{array}{l}\text { With } \\
\text { antibiotic }\end{array}$ & \\
\hline \multirow{7}{*}{$\begin{array}{c}\text { Exp. } 1 \\
\text { Bottromycin } A_{2} \\
1.25 \times 10^{-5} \mathrm{M}\end{array}$} & 0.7 & 1.4 & 2,867 & 705 & 75 \\
\hline & 1.4 & 1. 4 & 2,813 & 718 & 75 \\
\hline & 2.1 & 1.4 & 2,848 & 695 & 76 \\
\hline & 0.7 & 2.8 & 2,948 & 1,042 & 65 \\
\hline & 0.7 & 4.2 & 3,032 & 1,410 & 53 \\
\hline & 0.7 & 一 & 153 & & \\
\hline & - & 1.4 & 301 & & \\
\hline \multirow{5}{*}{$\begin{array}{c}\text { Exp. } 2 \\
\text { Bottromycin } A_{2} \\
2.5 \times 10^{-5} \mathrm{M}\end{array}$} & 0.7 & 1.4 & 4,408 & 695 & 84 \\
\hline & 1.4 & 1.4 & 4,358 & 653 & 85 \\
\hline & 2.8 & 1.4 & 4,288 & 640 & 85 \\
\hline & 0.7 & 2.8 & 4,631 & 985 & 79 \\
\hline & 0.7 & 5.6 & 4,752 & 1,633 & 66 \\
\hline \multirow{3}{*}{$\begin{array}{c}\text { Exp. } 3 \\
\text { Erythromycin } \\
5 \times 10^{-7} \mathrm{M}\end{array}$} & 0.7 & 1.4 & 3,759 & 675 & 81 \\
\hline & 2.1 & 1.4 & 3,673 & 659 & 82 \\
\hline & 0.7 & 4.2 & 3,965 & 1,345 & 66 \\
\hline
\end{tabular}

The reaction mixture contained in $0.1 \mathrm{ml}: 50 \mathrm{~mm}$ Tris- $\mathrm{HCl}, \mathrm{pH} 7.4,10 \mathrm{mM} \mathrm{Mg}$ acetate, $100 \mathrm{~mm}$ $\mathrm{NH}_{4} \mathrm{Cl}, 2 \mathrm{mM}$ dithiothreitol, $10 \mu \mathrm{g}$ poly A, $0.2 \mathrm{mg}$ protein of $\mathrm{S}-100,40 \mathrm{~m} \mu$ moles $\mathrm{GTP}, 4 \mathrm{~A}_{260}{ }^{14} \mathrm{C}$ lys-tRNA $(40,000 \mathrm{cpm})$, and ribosomal subunits and antibiotic as indicated. The reaction was allowed to proceed at $37^{\circ} \mathrm{C}$ for 15 minutes, and stopped by the addition of $10 \%$ TCA containing $0.1 \%$ phosphotungstic acid. After treatment at $90^{\circ} \mathrm{C}$ for 20 minutes the precipitates were collected on glass fiber paper, and the radioactivity was determined with a liquid scintillation counter. Ribosomes, S-100, and tRNA were prepared from $E$. coli B. Ribosomal subunits were separated by dialysis of ribosomes against $10 \mathrm{~mm}$ Tris-HCl buffer, $\mathrm{pH} 7.4$, containing $0.1 \mathrm{~mm} \mathrm{Mg}$ acetate, $100 \mathrm{~mm} \mathrm{NH}{ }_{4} \mathrm{Cl}$, and $2 \mathrm{mM}$ dithiothreitol at $4^{\circ} \mathrm{C}$ for 7 hours, followed by centrifugation on $8 \sim 30 \%$ sucrose gradient in a Beckman SW-25 rotor at $22,500 \mathrm{rpm}$ for 13 hours. $14 \mathrm{C}-\mathrm{LyS}-\mathrm{tRNA}$ was prepared as described in a previous paper ${ }^{22}$. Poly A was a product of Miles Laboratories, Inc., and ${ }^{4} \mathrm{C}$-lysine (248 $\left.\mathrm{mCi} / \mathrm{mmole}\right)$ was purchased from Daiichi Pure Chemicals Co. 
Fig. 1. Effect of pretreatment of ribosomal subunits with bottromycin $A_{2}$ on poly A-directed synthesis of polyiysine.

$30 \mathrm{~S}\left(0.7 \mathrm{~A}_{260}\right)$ or $50 \mathrm{~S}\left(1.4 \mathrm{~A}_{260}\right)$ subunit alone was preincubated in $0.1 \mathrm{ml}$ of $50 \mathrm{~mm}$ Tris- $\mathrm{HCl}$ buffer, $\mathrm{pH} 7.4$, containing $10 \mathrm{mM} \mathrm{Mg}$ acetate, 100 $\mathrm{mM} \mathrm{NH}{ }_{4} \mathrm{Cl}$, and $2 \mathrm{mM}$ dithiothreitol with $1.25 \times 10^{-5} \mathrm{M}$ bottromycin $\mathrm{A}_{2}$ at $35^{\circ} \mathrm{C}$ for 30 minutes. Then the complementary subunit $\left(0.7 \mathrm{~A}_{260} 30 \mathrm{~S}\right.$ or $1.4 \mathrm{~A}_{260}$ $50 \mathrm{~S}$ ) and other components were added to start polylysine synthesis. Final composition of the reaction mixture, except for ribosomal subunits and antibiotic, and the procedures for the assay were the same as in Table 1.

A : No bottromycin A; B:30S subunit preincubated; $C$ : Bottromycin $A_{2}$ added at the start of the reaction; $\mathrm{D}: 50 \mathrm{~S}$ subunit preincubated. Final concentration of the antibiotic in B, C, and $\mathrm{D}$ was the same.

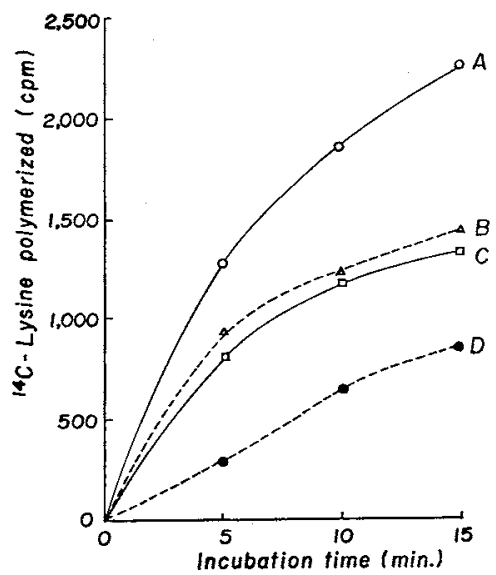

treatment of the $30 \mathrm{~S}$ subunit or addition of the antibiotic at the start of polylysine synthesis. This result also indicates that bottromycin $\mathrm{A}_{2}$ interacts preferentially with $50 \mathrm{~S}$ subunit.

\section{References}

1) Tamaka, N.; K. Sashikata, H. Yamaguchi \& H. UMEZAWA: Inhibition of protein synthesis by bottromycin $A_{2}$ and its hydrazide. J. Biochem. $60: 405 \sim 410,1966$

2) Lin, Y-C. \& N. Tanaka: Mechanism of action of bottromycin in polypeptide biosynthesis. J. Biochem. $63: 1 \sim 7,1968$

3) Tanaka, K.; H. TeraOka, T. Nagira \& M. TAMAKI: ${ }^{14} \mathrm{C}$-Erythromycin-ribosome complex formation and non-enzymatic binding of aminoacyl-transfer RNA to ribosomemessenger complex. Biochim. Biophys. Acta $123: 435 \sim 437,1966$

4) Taubman, S. B.; N. R. Jones, F. E. Young \& J.W. Corcoran: Sensitivity and resistance to erythromycin in Bacillus subtilis 168: The ribosomal binding of erythromycin and chloramphenicol. Biochim. Biophys. Acta $123: 438 \sim 440,1966$ 